\title{
DAMPAK EKONOMI WISATA BAHARI DI KABUPATEN ALOR
}

\section{An Economic Impact of Marine Tourism in the Alor Regency}

\author{
*Umi Muawanah, Riesti Triyanti, dan Permana Ari Soejarwo \\ Balai Besar Riset Sosial Ekonomi Kelautan dan Perikanan \\ Gedung BRSDM KP I Lt. 4 \\ Jalan Pasir Putih Nomor 1 Ancol Timur, Jakarta Utara, Indonesia \\ Telp: (021) 64711583 Fax: 64700924 \\ Diterima tanggal: 24 Maret 2020; Diterima setelah perbaikan: 12 Juni 2020; \\ Disetujui terbit: 30 Juni 2020
}

\begin{abstract}
ABSTRAK
Kabupaten Alor merupakan salah satu kabupaten di Provinsi Nusa Tenggara Timur yang memiliki potensi obyek wisata alam yang beragam, termasuk wisata alam bahari yang dapat mendukung perekonomian masyarakat Alor. Jumlah wisatawan yang mengunjungi kabupaten Alor pada tahun 2017 mengalami peningkatan sekitar $56 \%$ dari tahun sebelumnya. Dilihat dari banyaknya jumlah wisatawan yang mengunjungi Kabupaten Alor, maka diperlukan adanya penelitian terkait dengan pengaruh obyek wisata terhadap perekonomian masyarakat Alor. Penelitian ini bertujuan untuk menganalisis dampak ekonomi langsung kegiatan wisata, dampak tidak langsung, serta dampak ekonomi lanjutan. Penelitian ini menggunakan metode analisis multplier effect dengan menggunakan. data primer dan sekunder. Pengumpulan data dilakukan dengan bantuan kuesioner terstruktur dan wawancara responden, terdiri dari 50 wisatawan, 21 pengusaha bidang wisata bahari dan 11 tenaga kerja/karyawan dari unit usaha terkait wisata bahari. Lokasi penelitian yaitu Daerah Kalabahi, ibukota Kabupaten Alor sebagai sentra wisata bahari. Hasil analisis menunjukkan bahwa dampak ekonomi langsung yang diperoleh dari kegiatan wisatawan di Kalabahi sebesar Rp480.000.000 per tahun dan dampak ekonomi tidak langsung yang diperoleh dari kegiatan wisatawan di Kalabahi sebesar Rp201.600.019 per tahun, serta dampak ekonomi lanjutan kegiatan wisata bahari di Kalabahi sebesar Rp20.250.000 per tahun. Nilai Keynesian Income Multiplier yang diperoleh sebesar 1,72 yang artinya setiap terjadi peningkatan pengeluaran wisatawan sebesar 1 rupiah, maka akan berdampak terhadap peningkatan pendapatan tenaga kerja dan para pemilik unit usaha di lokasi wisata diduga sebesar 1,72 rupiah. Hal ini menunjukkan bahwa kegiatan wisata bahari di Kabupaten Alor memberikan dampak ekonomi positif dan cukup besar terhadap masyarakat Kabupaten Alor. Ke depannya, pemerintah Alor maupun pengusaha ekowisata bahari perlu membuat paket tour wisata di Alor untuk meningkatkan lamanya tinggal di Alor dan meningkatkan dampak ekonomi ke masyarakat lokal Alor.
\end{abstract}

Kata Kunci: wisata bahari; Kabupaten Alor; dampak langsung; dampak tidak langsung; dan efek penggandaan

\section{ABSTRACT}

Alor Regency is one of regency in East Nusa Tenggara Province. It offers a variety of natural tourist attraction including marine tourism which might support the economy of the people of Alor. The number of tourists visiting Alor Regency in 2017 has increased by around 56\% from the previous year. Considering the large number of tourists visiting Alor Regency, research is needed to estimate the impact of marine tourism activities on the economy of Alor community. This study aimed to analyze the direct, indirect, and continued economic impacts. This study used a multiplier effect analysis to analyze primary and secondary data. Data were collected by structured questionnaires and interview with 50 tourists, 21 entrepreneurs of marine tourism, and 11 workers of business units on marine tourism. The research was located in Kalabahi, the capital of Alor Regency as a marine tourism center. The analysis showed that the direct economic impact from tourist activities in Kalabahi amounted to IDR.480,000,000 per year and the indirect economic impacts from tourist activities in Kalabahi amounted to IDR 201,600,019 per year, as well as the continued economic impact of marine tourism activities in Kalabahi amounted to IDR 20,250,000 per year. The Keynesian Income Multiplier is 1.72, which means that if there is an increase in tourist spending by 1 IDR, it will have an impact on increasing labor income and business unit owners in 
tourist sites at about 1.72 IDR. This shows that marine tourism activities in Alor Regency have a positive and significant economic impact on the people of Alor Regency. In the future, it is necessary for Alor government and marine ecotourism entrepreneurs to create tour packages in Alor to increase the length of stay in Alor. Therefore, it will increase the economic impact of marine tourisme on the economy of the local community in Kalabahi, Alor.

Keywords: marine tourism; Alor Regency; direct impact; indirect impact; and multiplier effect

\section{PENDAHULUAN}

Kabupaten Alor merupakan wilayah yang secara geografis terletak pada $8^{\circ} 6^{\prime}$ LS - $8^{\circ} 36^{\prime}$ LS dan $123^{\circ} 48^{\prime}$ BT $-25^{\circ} 48^{\prime}$ BT, sebelah utara berbatasan dengan Laut Flores Selatan berbatasan dengan Selat Ombay dan Timor Leste, sebelah Timur berbatasan dengan pulau-pulau Maluku dan bagian barat berbatasan dengan Selat Lembata. Luas Kabupaten ini mencapai 13.638,26 km² dengan wilayah laut lebih luas daripada wilayah darat yaitu $10.773,62 \mathrm{~km}^{2}$ atau sekitar $79 \%$ sedangkan wilayah darat mempunyai luas $2.864,64 \mathrm{~km}$ atau sekitar $21 \%$ pada tahun 2009 .

Kabupaten Alor memiliki objek wisata yang sangat beragam baik alam maupun budaya masyarakatnya. Alor juga memiliki potensi arkeologi yang unik (Rema \& Prihatmoko, 2016). Wisata alam tidak hanya wilayah daratan dengan suasana pegunungan yang sejuk dan memikat, namun juga wisata bahari yang sangat indah. Wisata bahari yang dimiliki alor sangat beragam, mulai dari wisata pesisir, wisata bawah laut, serta wisata komoditas laut yang langka. Terkait wisata budaya, Alor terkenal dengan keberagaman suku yang memiliki kekhasan tersendiri baik suku pengunungan maupun suku-suku di wilayah pesisir. Salah satu suku tersebut disebut suku Makassar yang merupakan suku migran dari Sulawesi Selatan (Patji, 2009). Menurut data dari Pemerintah Provinsi Nusa Tenggara Timur (2018), Kabupaten Alor memiliki 21 daya tarik wisata alam dan sebagian merupakan wisata bahari .

Jumlah wisatawan domestik yang mengunjungi Kabupaten Alor pada tahun 2017 sebanyak 4051 orang, hal ini menunjukkan terjadinya peningkatan dari tahun sebelumnya sebesar 2289 orang. Peningkatan jumlah ini juga terjadi pada wisatawan mancanegara yang sebelumnya berjumlah 27 orang, pada tahun 2017 sebanyak 94 orang (BPS Provinsi NTT, 2018). Adanya tingkat antusiasme wisatawan terhadap potensi wisata yang ada akan memengaruhi perekonomian di Kabupaten Alor.
Pariwisata bahari akan memberikan manfaat positif secara ekonomi seperti wisata bahari di Lamongan dan kadang mampu memberikan manfaat perbaikan ekosistem seperti wisata snorkeling di Karimunjawa (Efrilingga (2014); Priyanto \& Par (2016)). Dampak positif dari keberadaan Wisata Bahari Lamongan adalah: (1) Meningkatkan keterampilan penduduk masyarakat; (2) Munculnya transformasi struktur mata pencaharian; (3) Meningkatkan Pendapatan; (4) Menciptakan Lapangan Pekerjaan, dan; (5) Mendorong aktivitas berwirausaha. Hal ini tampaknya terjadi di Kabupaten Alor dari maraknya wisata bahari di sana. Akan tetapi, tidak jarang wisata bahari juga memberikan dampak negatif seperti penurusan kualitas ekosistem laut seperti ekowisata di Nusa Penida (Jubaedah \& Anas, 2019). Pariwisata bahari di Kawasan Konservasi Perairan Nusa Penida berdampak pada penurunan luasan tutupan karang keras sebesar $4,0 \%$. Demikian juga persentase penutupan karang hidup relatif mengalami penurunan sebesar 2,7 pada tahun 2017 (Jubaedah \& Anas, 2019).

Alor adalah pulau kecil yang memiliki potensi wisata yang besar. . Ekowisata menekankan pada wisata berbasis lingkungan dan berdasarkan kapasitas daya tampung lingkungan, merupakan kebalikan dari mass tourism. Kesejahteraan masyarakat sekitar tempat wisata akan meningkat apabila jumlah wisata yang tidak banyak tersebut tinggal lebih lama di masyarakat dan bertransaksi dengan kegiatan-kegiatan ekonomi lokal yang sudah ada di masyakarat (Yasa, 2015). Penelitian ini bertujuan memperkirakan dampak ekonomi yang diberikan oleh sektor pariwisata di Kabupaten Alor, terutama di pusat wisata bahari yaitu Kalabahi.

Ekowisatatermasukdalam kategori pariwisata alternatif. Bentuk produk pariwisata alternatif yang dapat dikembangkan seperti; pariwisata budaya (cultural tourism), pariwisata bahari (marine tourism), pariwisata petualangan (adventure 
tourism), pariwisata agro (agrotourism), pariwisata pedesaan (village tourism), pariwisata gastronomi (cultinary tourism), ekowisata (ecotourism), wisata perdesaan (village tourism) (Subadra \& Nadra, 2012).

Potensi Ekowisata Kabupaten Alor sangat besar dan memungkinkan untuk dikembangkan, oleh sebab itu perlu dilakukan penelitian yang bertujuan menganalisa dampak ekonomi wisata bahari di Kabupaten Alor. Penelitian ini bertujuan mengetahui jenis potensi wisata bahari yang ada di Kabupaten Alor serta dampak ekonomi wisata bahari terhadap unit kegiatan usaha di Kabupaten Alor.

\section{METODOLOGI}

\section{Lokasi dan waktu Penelitian}

Penelitian ini dilakukan di Desa Kabola, Kabupaten Alor, Nusa Tenggara Timur (NTT) pada bulan Juni-Juli 2019.

\section{Jenis dan Metode Pengambilan Data}

Data yang dikumpulkan berupa data primer dan sekunder sesuai dengan tujuan penelitian. Data primer berupa merupakan data ekonomi yang ditanyakan kepada respondent di lokasi penelitian. Adapun data sekunder berupa data jumlah wisatawan dari BPS Provinsi NTT tahun 2018.
Teknik pengumpulan data primer dilakukan dengan beberapa cara, yaitu:

1. Wawancara terstruktur, yaitu wawancara dengan menggunakan alat bantu berupa kuesioner. Wawancara terstruktur dilakukan dalam pengumpulan data ekonomi meliputi demografi, aktifitas ekonomi (penerimaan, upah tenaga kerja dan pengeluaran) kepada responden. Responden survei meliputi wisatawan, unit usaha sektor wisata bahari dan tenaga kerja sektor wista bahari. Pengambilan data bisa dengan menggunakan tenaga enumerator.

2. Wawancara mendalam, yaitu wawancara yang dilakukan melalui tahap muka antara peneliti dan responden, bersifat diskusi antar pribadi secara intensif dan mendalam tentang suatu topik. Alat bantu yang dipakai peneliti berupa topik data.

3. Focus Group Discussion (FGD). Pengambilan data dilakukan melalui diskusi kelompok yang dihadiri oleh berbagai stakeholders (Dinas Kelautan dan Perikanan, Dinas Pariwisata, Badan Perencanaan Pembangunan Daerah, Lembaga Swadaya Masyarakat (WWF Indonesia), Agen tur, Dewan Perwakilan Masyarakat, Universitas Tribuana Kalabahi, dan Pemilik resort.

4. Observasi. Pengambilan data dilakukan dengan pengamatan langsung dan

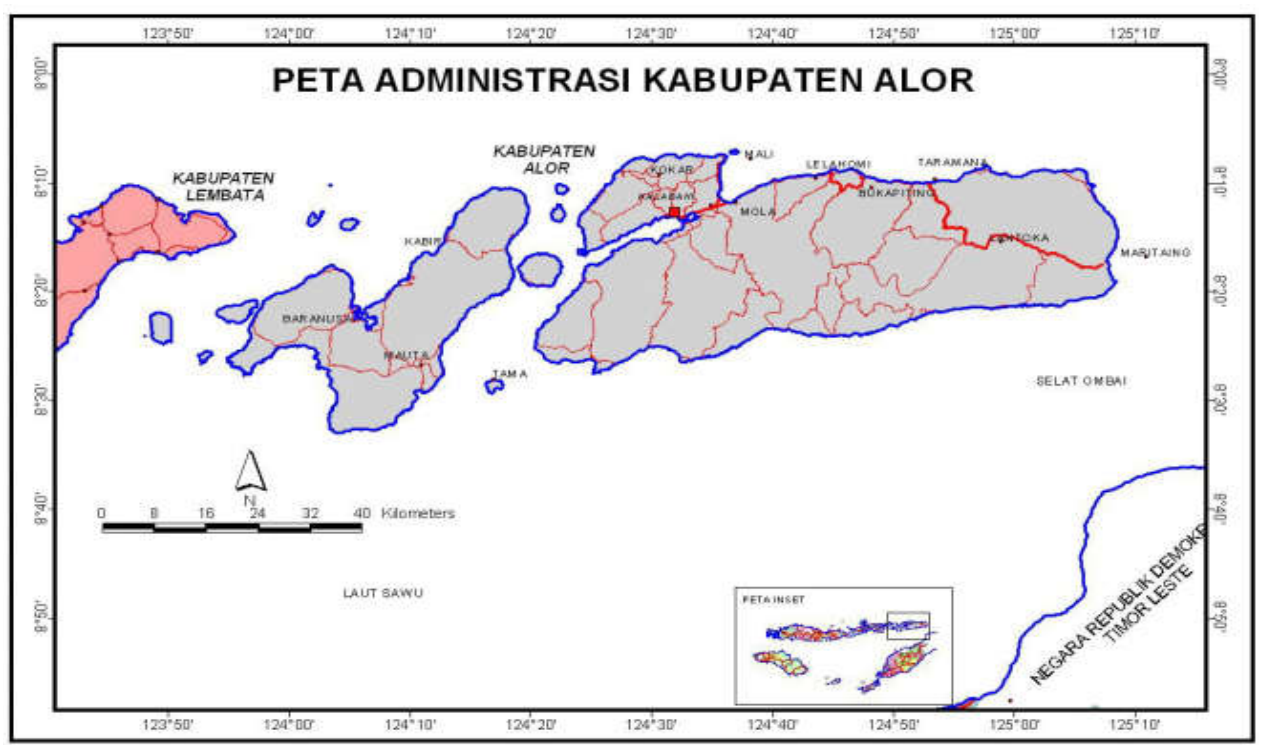

Gambar 1. Peta Administrasi Kabupaten Alor.

Figure 1. Map of the District of Alor.

Sumber: alorkab.go.id/ Source: alorkab.go.id 
pencatatan secara sistematis terhadap objek yang diteliti dalam penentuan potensi wisata bahari berbasis potensi alam dan potensi budaya bahari.

Survei dan analisa dipusatkan di Kalabahi sebagai pusat wisata bahari di Alor. Identifikasi jumlah responden berdasarkan jumlah wisatawan, jumlah unit usaha sektor wisata bahari dan tenaga kerja di unit-unit usaha pariwisata bahari. Jumlah responden dalam survei dampak ekonomi adalah 50 wisatawan, 21 pemilik usaha sektor wisata bahari dan 11 tenaga kerja sektor wisata bahari. Responden yang diwawancarai adalah yang bersedia dan berada di lokasi.

\section{Metode Analisis}

Analisis efek pengganda Output (Multiplier Effect)

Untuk mengestimasi nilai ekonomi yang dibangkitkan oleh model ekonomi kreatif wisata bahari berbasis budaya bahari dan kearifan lokal, maka digunakan analisis Multiplier Effect (Pengganda Output) (Frechtling and Horvath, 1999). Pengganda output yaitu dampak peningkatan permintaan akhir suatu sektor di suatu wilayah. Pengganda output sederhana adalah kenaikan permintaan akhir suatu sektor dalam perekonomian suatu wilayah terhadap kenaikan output sektor yang lain baik secara langsung maupun tidak langsung. Pengganda output total yaitu dampak kenaikan permintaan akhir suatu sektor dalam perekonomian suatu wilayah terhadap kenaikan output sektor yang lain baik langsung maupun tidak langsung dan dampak induksinya. Pada sektor wisata, efek pengganda wisata menunjukkan total peningkatan ouput, peningkatan penambahan pendapatan pelaku wisata melalui interlink dalam ekonomi kewilayahan karena peningkatan pengeluaran wisata (Frechtling \& Horvath, 1999).

Pendekatan dalam perkiraan kontribusi ekonomi sektor pariwisata biasanya menggunakan analisis input-output untuk memperkirakan dampak ekonomi dari total pengeluaran wisatawan. Di Amerika, Australia dan Inggris, metode yang paling sering dipakai adalah metode Computable General Equilibrium (CGE) model and Money Generation Model (MGM) (Kumar \& Hussain, 2014). Selain itu, model lain dapat digunakan seperti model Keynesian, model berdasarkan nilai expor, dan model ad-hoc. Dampak dari pengeluaran dalam bentukpenjualan, pendapatan, jumlah pekerjaan dan pajak penghasilan. Dalam kajian ini, menggunakan model Dampak Ekonomi dengan Keynesian Model META (2001), untuk mengestimasi dampak ekonomi sektor wisata bahari.

Dampak ekonomi ini dapat diukur dengan menggunakan efek pengganda atau multiplier effect dari arus uang yang terjadi. Konsep multiplier effect ini sudah banyak dikenal dan digunakan untuk mengukur dampak ekonomi pada bidang pariwisata (Hughes, 1994). Berdasarkan META (2001), pengukuran dampak ekonomi terdiri dari tiga dampak, yaitu dampak langsung, tidak langsung, dan dampak lanjutan. Dampak langsung terjadi apabila spending wisatawan langsung masuk ke kawasan wisata, sedangkan dampak tidak langsung berupa pengeluaran pihak pengelola untuk membayar upah tenaga kerja. Dampak lanjutan berupa perubahan aktivitas ekonomi di lokasi wisata dari pembelanjaan tenaga kerja tersebut untuk memenuhi kebutuhannya.

Menurut Vanhove (2005), analisis dilakukan untuk setiap kelompok pelaku kegiatan wisata seperti kelompok unit usaha lokal penyedia barang dan jasa pendukung kegiatan wisata, diantaranya adalah unit usaha lokal yang menyediakan barang dan jasa untuk kegiatan wisata serta tenaga kerja lokal yang berperan dalam menyediakan kebutuhan barang dan jasa pendukung kegiatan wisata. Berdasarkan Marine Ecotourism for Atlantic Area (2001), pengukuran dampak ekonomi terhadap masyarakat lokal dapat dilakukan menggunakan dua tipe pengganda diantaranya adalah Keynesian Local Income Multiplier Effect yang dapat menunjukkan estimasi besaran pengeluaran pengunjung yang berpengaruh terhadap peningkatan pendapatan masyarakat lokal serta Ratio Income Multiplier yang dapat menunjukkan estimasi besaran dampak langsung yang dirasakan dari pengeluaran pengunjung terhadap perekonomian lokal. Income Multiplier didefinisikan juga sebagai hasil bagi dari perubahan dalam keseimbangan Produk Domestik Bruto (PDB) dengan perubahan pengeluaran awal (Beckenstein, Appleyard \& Christmann, 2008). Melalui multiplier effect-nya, pariwisata dapat dan mampu mempercepat pertumbuhan ekonomi dan penciptaan lapangan kerja (Kurniasari et al., 2018). Struktur masyarakat pesisir umumnya berupa gabungan dari karakteristik masyarakat perkotaan dan pedesaan, namun masih tetap memiliki jiwa kebersamaan. Berbeda dengan itu, menurut data Kementerian Perencanaan Pembangunan Nasional Republik Indonesia/PPN B (2003) bahwa Alor memiliki aneka ragam bahasa lokal mencapai 19 
etnolinguistik, kesenian tradisional, upacara adat dan kearifan lokal, tak heran jika perkampungan tradisional di Kabupaten Alor juga menjadi daerah tujuan wisata. Masyarakat pesisir Alor juga memiliki sifat yang khas terutama yang berkaitan dengan sifat usaha dibidang kelautan dan perikanan itu sendiri (Wahyudin, 2015).

Pengukuran dampak ekonomi dalam penelitian meliputi dua kelompok, yaitu: 1) survei terhadap unit usaha penyedia barang dan jasa dan 2) survei terhadap tenaga kerja pada unit usaha di kawasan wana wisata. Survei terhadap unit usaha merupakan dampak langsung. Dampak terhadap unit usaha membutuhkan informasi terkait (1) proporsi perputaran uang yang berasal dari pengeluaran pengunjung ke unit usaha tersebut, (2) proporsi dari perputaran arus uang terhadap tenaga kerja lokal, supplier, dan pajak, dan (3) tipe dan kuantitas bahan baku yang dibutuhkan.

Kelompok kedua adalah tenaga kerja lokal pada unit usaha lokal penyedia barang dan jasa untuk kegiatan wisata bahari. Tenaga kerja adalah dampak tidak langsung. Informasi terkait dengan dampak ekonomi adalah (1) jumlah tenaga kerja yang terdapat pada kawasan wisata, (2) jumlah jam kerja dan tingkat upah, (3) proporsi dari pengeluaran seharihari pekerja yang dilakukan di dalam dan di luar wilayah kawasan wisata, dan (4) kondisi pekerjaan sebelum bekerja di unit usaha saat ini. Estimasi terhadap unit usaha yang memberikan nilai dampak ekonomi terhadap manfaat dan biaya masyarakat lokal dan penyediaan barang dan jasa yang diperlukan pengunjung. Pengukuran dampak ekonomi lokal kegiatan pariwisata melalui dua tipe efek pengganda, yaitu (META, 2001):

1). Keynesian Income Multiplier (KIM) adalah perubahan unit pengeluaran wisatawan memberikan perubahan pada tingkat pendapatan masyarakat lokal. Secara matematis ditulis:

$$
K I M=\frac{D+N+U}{E}
$$

2). Income Multiplier Ratio adalah efek multiplier yang menggambarkan seberapa besar dampak terhadap perekonomian lokal. Multiplier ini telah memasukkan dampak lanjutan dan dampak tidak langsung.

Ratio Income MultiplierTipe I, secara matematis ditulis:

$$
R I M=\frac{D+N}{D}
$$

Ratio Income MultiplierTipe II, secara matematis ditulis:

$$
R I M=\frac{D+N+U}{D}
$$

Keterangan/Remarks: :

$\mathrm{D}=$ Pendapatan lokal yang diterima secara langsung dari $\mathrm{E}(\mathrm{Rp}) /$ Local income received directly from $E$ (IDR);

$\mathrm{N}=$ Pendapatan lokal yang diterima secara tidak langsung dari $\mathrm{E}(\mathrm{Rp}) /$ Local income received indirectly from $E$ (IDR);

$\mathrm{E}=$ Tambahan pengeluaran wisatawan (Rp)/ Additional tourist expenses (IDR;

$\mathrm{U}=$ Pendapatan lokal yang diterima secara lanjutan dari $\mathrm{E}(\mathrm{Rp}) /$ Local income received further from $E$ (IDR).

$D E T L=(P P T K+P D T K+P N U U)$

Keterangan/Remarks: :

PPTK = Populasitenagakerja(orang)/Laborpopulation (People)

PDTK = Pendapatan tenaga kerja (Rp/tahun)/ Labor income (IDR/year)

PNUU = Pengeluaran unit usaha di kawasan wisata (Rp/tahun)/ Expenditures of business units in tourist areas (IDR/year)

DETL = Dampak ekonomi tidak langsung / Indirect economic impact

Multiplier effect memiliki kriteria-kriteria, sebagai berikut:

- Jika nilai koefisien multiplier tersebut kurang atau sama dengan nol $(\leq 0)$, maka aktivitas wisata belum mampu memberikan dampak ekonomi terhadap kawasan wisata;

- Jika nilai koefisien multiplier diantara nol dan satu $(0 \leq$ RIM $\leq 1)$, maka aktivitas wisata memberikan nilai dampak ekonomi yang rendah;

- Jika nilai koefisien multiplier tersebut lebih atau sama dengan satu $(\geq 1)$, maka aktivitas wisata mampu memberikan dampak ekonomi terhadap kawasan wisata.

- Putra, Wijayanti \& Prasetyo (2017) menyebutkan bahwa Keynesian Income Multiplier merupakan metode terbaik dalam merefleksikan keseluruhan dampak dari pengeluaran dari kegiatan ekowisata bahari terhadap aktifitas ekonomi di wilayah tersebut. 


\section{HASIL DAN PEMBAHASAN}

\section{Potensi Wisata Bahari dan Aktivitas Ekonomi Kreatif Berbasis Kearifan Lokal Kelautan dan Perikanan}

Potensi wisata bahari meliputi bentangan alam dan budaya bahari yang sudah mulai dikembangkan atau akan dikembangkan sebagai produk atau jasa dalam pengembangan wisata bahari. Berikut adalah lokasi potensi wisata bahari dan aktivitas ekonomi kreatif berbasis kearifan lokal kelautan dan perikanan yang ada di Kabupaten Alor:

\section{Pantai Mali}

Pantai Mali terletak di Desa Kabola Kecamatan Tanjung Mutiara. Objek wisata yang terdapat di pantai ini adalah hamparan pasir putih, tempat perisitirahatan berupa gazebo-gazebo dengan pepohonan yang cukup rindang. Dari pantai ini akan terlihat Pulau Sika dimana di perairan antara Pantai Mali dan Pulau Sika terdapat dugong yang jinak. Dugong yang diberi nama mawar ini dapat dilihat dan berinteraksi dengan pengunjung. Pantai Mali juga menjadi tempat utama festival Panggil Dugong yang menjadi agenda wisata tahunan Pulau Alor. Pantai ini dikelola oleh Dinas Pariwisata, namun ketika penelitian berlangsung kondisinya masih memerlukan banyak perbaikan.

\section{Pantai Mailmol}

Lain halnya dengan Pantai Mali, Pantai Mailmol dikelola oleh perorangan. Pantai Mailmol ini terbagi menjadi dua wilayah, yaitu wilayah yang dikelola sebagai objek wisata private artinya hanya orang-orang tertentu saja yang bisa masuk, dan daerah wisata umum yaitu siapa pun bisa mengakses daerah wisata tersebut. Adapun Pantai Mailmol ditunjukkan oleh Gambar 2.

\section{Pantai Buiko}

Pantai Buiko terletak satu garis dengan Pantai Mali dan Mailmol. Di Pantai ini wisatawan dapat menikmati suasana hutan mangrove dan pesisir pantai yang ditumbuhi banyak pohon kelapa.

\section{Pantai Pantai Pasir Tiga Warna}

Pantai ini terdapat di Kecamatan Pantar yang lebih dikenal dengan Pantai Puntaru. Warna yang terpancar di pantai ini adalah hitam bercampur merah, kuning, biru, dan putih. Pantai ini menghadap selat Ombay. Hal yang membuatnya sangat indah karena pantai ini berada di bawah kaki Gunung Sirung

\section{Pantai Sebanjar}

Pantai Sebanjar berjarak kurang lebih 20 $\mathrm{km}$ dari Kota Kalabahi. Di pantai ini wisatawan dapat menikmati keindahan pantai yang dipenuhi dengan serpihan batu karang, air laut yang bersih, juga dapat menikmati keindahan terumbu karang dengan ikan-ikan hias yang beragam. Selain itu, pengunjung dapat bersantai di gajebo-gajebo yang tersedia di tepi pantai, atau bersantai sambil menikmati kopi dan makanan ringan di cafe yang ditata secara kreatif oleh pengelola wilayah ini. Bagi pengunjung yang ingin merasakan sensasi menginap di pinggir pantai, disediakan juga cottage yang terawat dengan fasilitas yang cukup memadai. Suasana Pantai Sebanjar ditunjukkan oleh Gambar 3

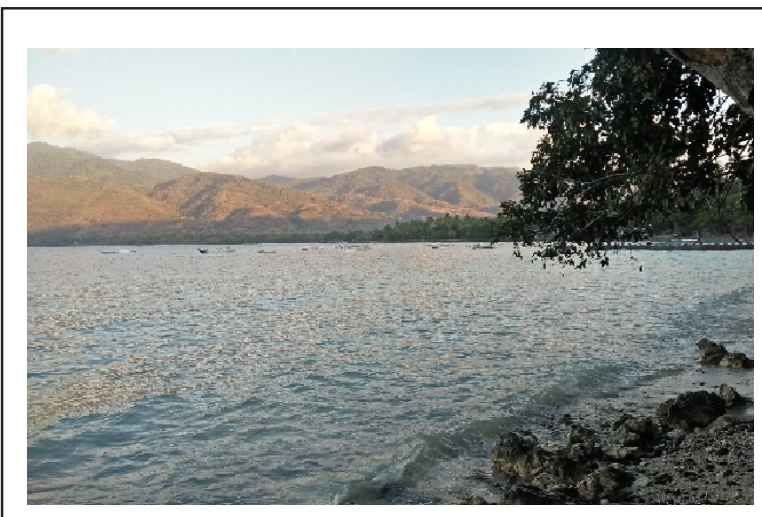

a. Suasana Pantai Mailmol/Condition at Mailmol Beach

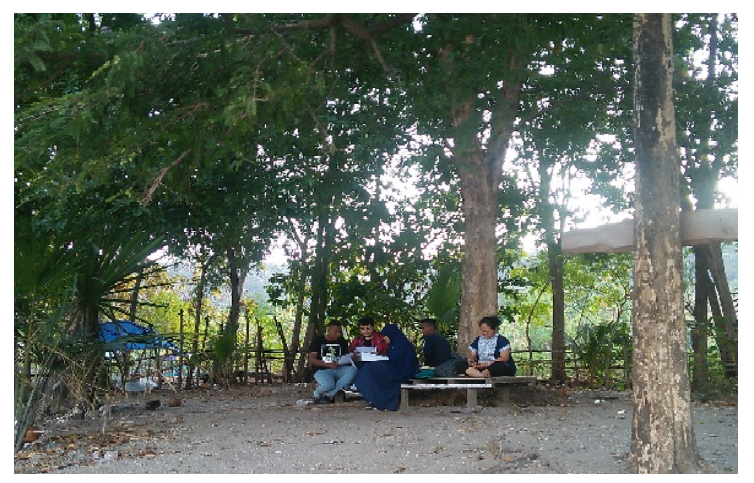

b. Survei riset di Pantai Mailmol/ Reserach Survei at Mailmol Beach

Gambar 2. Suasana Pantai Mailmol.

Figure 2. The Conditions of Mailmol Beach. 


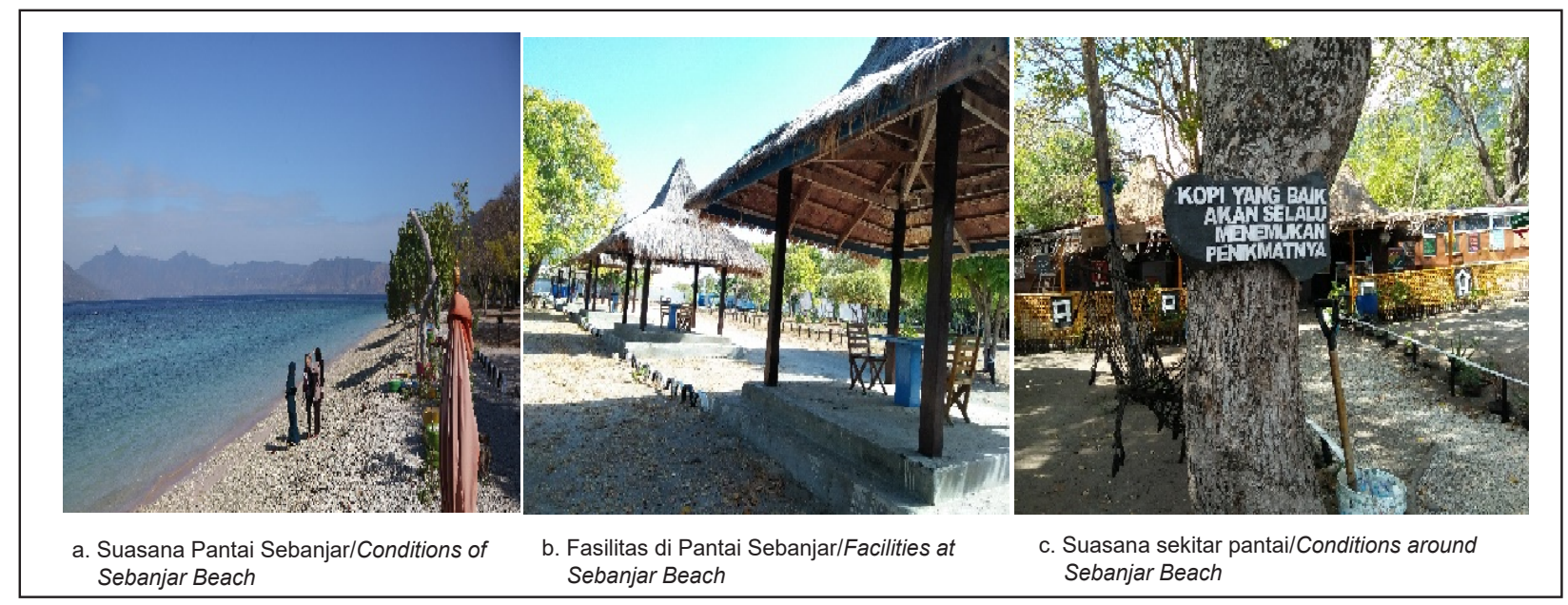

Gambar 3. Suasana Pantai Sebanjar.

Figure 3. The Conditions of Sebanjar Beach.

\section{Taman Laut Alor}

Alor terkenal dengan pemandangan alam bawah laut terindah di dunia setelah Karibia. Taman laut ini kaya dengan berbagai biota laut yang sangat beragam. Taman Laut alor tersebar dibeberapa titik diantaranya di Pulau Pantar, Pulau Ternate, Alor Kecil, Pulau Buaya, dan bagian Selatan Alor.

\section{Pantai Batu Putih}

Pantai Batu Putih berada di Desa Alila Timur Kecamatan Kabola yang bisa ditempuh sekitar 30 menit dari Kalabahi. Penamaan Pantai Batu Putih diambil dari keberadaan tebing-tebing berwarna putih di daerah tersebut. Aktivitas yang dapat dilakukan di daerah ini adalah berenang, snorkling, diving, berkeliling laut dengan memakai perahu, dan berisitirahan di bawah tebing-tebing yang indah. Pantai Batu Putih merupakan salah satu pantai kebanggaan warga Alor, tak heran jika pantai ini selalu ramai dikunjungi wisatawan baik di hari libur maupun hari biasa.

\section{Fenomena Air Laut Dingin}

Berdasarkan informasi dari Dinas Pariwisata Alor (2019) perairan di sekitar Pulau Alor tidak hanya cantik tapi juga memiliki keunikan dari fenomena alam. Sekira dua kali dalam setahun, di perairan Alor terjadi fenomena yang disebut arus dingin di Selat Kumbang, yang terletak antara Desa Alor Kecil dan Pulau Kepa. Arus yang membawa air bersuhu dingin bergerak melalui perairan tersebut sekitar Bulan Mei dan September selama 2-3 hari berturut-turut. Fenomena ini ditandai dengan datangnya gerombolan ikan ke pinggir pantai dan pergerakan lumba-lumba dan burung pemakan ikan secara besar-besaran. Ikan-ikan terdampar yang jumlahnya terbilang banyak akan ditangkap masyarakat menggunakan alat-alat sederhana, seperti serok bahkan gayung. Untuk sampai ke Alor Kecil dapat menggunakan transportasi umum jurusan Alor Kecil dari ibukota Kalabahi, waktu tempuh perjalanan sekitar 15-30 menit.

Keberagaman suku, agama dan sumber daya menjadi faktor pembentuk keberagaman budaya dan pola kehidupan masyarakat di Alor, tak terkecuali pada masyarakat pesisirnya. Budaya masyarakat pesisir Alor kental dengan perpaduan dari budaya lokal yang banyak dipengaruhi budaya darat dengan budaya dari luar yaitu dari para pendatang baik nelayan maupun para pedagang. Selain itu, sejarah dan legenda yang dimiliki oleh masyarakat alor memiliki pesona tersendiri. Budaya, sejarah dan legenda tersebut dapat menjadi sumber ide bagi penciptaan produk-produk kreatif. Berdasarkan keunikan-keunikan yang ada, pantai-pantai yang ada di Alor berpotensi untuk dikembangkan lebih optimal untuk mendukung percepatan ekonomi kabupaten Alor.

\section{Estimasi Dampak Ekonomi untuk Wisata Bahari di Alor}

Pariwisata memberikan keuntungan berupa dampak positif dan negatif bagi suatu daerah (Mathieson \& Wall, 1982). Pariwisata juga memiliki pengaruh yang cukup besar dalam meningkatkan pendapatan usaha masyarakat (Aryunda, 2011). Rahma \& Handayani (2013) telah 
mengkaji tentang dampak dari aktivitas pariwisata di Kabupaten Kudus terhadap pendapatan perekonomian masyarakat sekitar tempat wisata. Penerima manfaat dari efek langsung dan tidak langsung menghabiskan pendapatan mereka yang meningkat untuk konsumsi atau barang investasi (Khan, Phang \& Toh, 1995). Dampak pariwisata dilihat dari besarnya nilai pengganda (turn over atau multiplierr effect) yang dapat dilihat dari nilai coefficient of multiplier sebagai akibat pengaruh jumlah pengeluaran wisatawan di lokasi wisata (Mulyadi \& Santoso, 2013). Pengukuran dampak ekonomi dari kegiatan pariwisata di Kabola, Alor dilakukan dengan analisis multiplier effect. Analisis dilakukan untuk mengestimasi dampak langsung, dampak tidak langsung dan dampak lanjutan dari kegiatan pariwisata di Kabola, Alor.

Sebelum menganalisis dampak ekonomi dari suatu kegiatan wisata, diperlukan analisis terlebih dahulu terkait dengan karakteristik sosial ekonomi dari wisatawan, unit usaha dan tenaga kerja yang terlibat dalam kegiatan wisata tersebut. Adapun uraian dari beberapa karakteristik tersebut seperti dibawah ini:

\section{Karakteristik Sosial Ekonomi Wisatawan}

Karakteristik sosial ekonomi wisatawan dilihat dari umur, pendidikan terakhir, jenis pekerjaan, pendapatan per bulan, asal daerah, cara kedatangan wisatawan, dan jumlah rombongan. Berdasarkan umur, wisatawan yang datang ke kawasan wisata bahari di Kelurahan Kabola berusia 19-57 tahun, dengan rata-rata usia wisatawan berusia 32 tahun. Hal ini terjadi karena wisatawan yang datang didominasi oleh PNS dan wirausahawan, yang membutuhkan penyegaran (refreshing) saat weekend (sabtu-minggu) maupun hari-hari libur. Pada tahun 2018, wisatawan yang mengunjungi Kabupaten Alor sebanyak 18.145 orang, dimana $80 \%$ didominasi oleh wisatawan lokal dan $20 \%$ dari wisatawan manca negara (BPS NTT, 2018). Adapun wisatawan didominasi oleh wisatawan lokal yang berasal dari Kalabahi (Ibu Kota Kabupaten Alor) dan kecamatan lain di sekitarnya. Berdasarkan pekerjaan sebanyak $6 \%$ adalah mahasiswa, 34\% adalah PNS, $1 \%$ adalah TNI/ Polri, $14 \%$ adalah Pegawai swasta, $20 \%$ wiraswasta, dan pekerjaan lainnya sebesar $23 \%$. Berdasarkan pendapatan wisatawan rata-rata pendapatan perbulan wisatawan adalah Rp2.772.000 per bulan. Berdasarkan cara kedatangan wisatawan ke kawasan wisata bahari di Kabola umumnya bersama keluarga atau rombongan, dengan jumlah rombongan sebanyak 9 orang. Jumlah pengeluaran wisatawan untuk melakukan kegiatan wisata bahari di Kabola berasal dari 43,96\% transportasi (taksi dan angkutan darat lainnya), $4,51 \%$ berasal dari tiket masuk (khusus Pantai Mali), 10,73\% berasal dari konsumsi, 32,48\% berasal dari biaya wisata di kawasan (sewa motor, sewa lopo-lopo, sewa ban), 8,32\% dari biaya lainnya (parkir, toilet, dan lain-lain).

\section{Karakteristik Sosial Ekonomi Unit Usaha}

Sebanyak $100 \%$ unit usaha skala kecil yang ada di Kelurahan Kabola merupakan penduduk asli yang ikut memanfaatkan peluang usaha seiring berkembangnya kegiatan wisata bahari di Kabola. Jenis usaha yang dimiliki masyarakat yang ada di kawasan wisata bahari di Kabola, diantaranya adalah warung kelontong, pedagang kaki lima penjual makanan kecil, sewa alat, sewa lopo-lopo, jasa wisata, pedagang keliling, dan unit campuran (homestay dan cafe). Unit usaha ini potensial untuk dikembangkan karena jumlah total unit usaha baru 24 unit.

\section{Karakteristik Sosial Ekonomi Tenaga Kerja}

Kelurahan Kabola merupakan salah satu kawasan wisata bahari di Kabupaten Alor yang saat ini sedang di kembangkan untuk obyek pariwisata (pembangunan infrastruktur). Saat ini, tenaga kerja yang terlibat di kawasan wisata di Kabola adalah $61 \%$ masyarakat lokal dari Kalabahi dan Kecamatan Kabola dan 39\% berasal dari luar kecamatan dan kabupaten (Kec. Mataru, Kec. Pantar Timur, maupun dari Batam). Jenis pekerjaan yang dilakukan yaitu karyawan café, penjaga tiket, security, tenaga latihan, dan instruktur diving. Adapun manfaat yang dapat dirasakan oleh tenaga kerja lokal dengan semakin berkembangnya kegiatan wisata bahari di Kabola adalah peningkatan pendapatan, peningkatan pengetahuan, dan ketersediaan lapangan pekerjaan. Rata-rata pendapatan per bulan yang diterima oleh tenaga kerja di kawasan wisata bahari Kelurahan Kabola berkisar Rp200.000 - Rp1.500.000 per bulan, dengan pendapatan rata-rata sebesar Rp1.143.308 per bulan dibawah UMK Kabupaten Alor pada tahun 2019 sebesar Rp1.793.298 per bulan.

\section{Analisis Dampak Ekonomi Kegiatan Wisata}

Analisis dampak ekonomi dapat melacak aliran pengeluaran oleh pengunjung dalam ekonomi lokal untuk memperkirakan kontribusi wisata atau taman nasional terhadap penjualan, pendapatan, 
dan pekerjaan di daerah tersebut (Stynes, Propst, Chang \& Sun, 2000). Adanya kegiatan wisata bahari di Kabola akan menimbulkan dampak terhadap masyarakat sekitar. Dampak yang muncul dari suatu kegiatan wisata, yaitu munculnya dampak ekonomi. Dampak ekonomi tersebut dapat bersifat positif dan negatif. Dampak positif yang muncul dari adanya dampak ekonomi dapat bersifat langsung (direct). Selain dampak positif langsung yang muncul, ada dampak lain yang akan timbul, seperti dampak tidak langsung (indirect impact). Dampak tidak langsung berupa aktivitas ekonomi lokal dari suatu pembelanjaan unit usaha penerima dampak langsung dan dampak lanjutan (induced impact). Dampak lanjutan ini dapat diartikan sebagai aktivitas ekonomi lokal lanjutan dari tambahan pendapatan masyarakat lokal. Dampak ekonomi yang ditimbulkan dari kegiatan wisata pada dasarnya dilihat dari keseluruhan pengeluaran wisatawan untuk akomodasi, konsumsi (baik konsumsi dari rumah maupun di lokasi wisata), biaya perjalanan ke lokasi wisata, pembelian souvenir, serta pengeluaran lainnya. Keseluruhan dari biaya pengeluaran wisatawan akan diestimasi dari jumlah keseluruhan kunjungan wisatawan dengan rata-ratapengeluaran dalam satu kali kunjungan wisata.

Dampak ekonomi langsung dari kegiatan wisata bahari yang ada di Kabola berasal dari aktivitas ekonomi yang terjadi antara wisatawan dengan masyarakat lokal yang memiliki unit usaha di lokasi wisata tersebut. Keberadaan unit usaha di suatu lokasi wisata membantu para wisatawan untuk memenuhi kebutuhan mereka selama melakukan kegiatan wisata. Rata-rata pengeluaran wisatawan yang berkunjung ke kawasan wisata pantai di Kabola sebesar Rp461.771,-. Biaya tersebut terdiri dari biaya bersih berupa pengeluaran wisatawan yang secara langsung masuk ke lokasi wisata selama berwisata antara lain digunakan untuk konsumsi di lokasi, penginapan, dan kebutuhan lainnya. Dampak ekonomi langsung yang diperoleh dari kegiatan wisatawan di Kabola sebesar Rp480.000.000 per tahun (Tabel 1).

Dampak ekonomi tidak langsung (indirect impact) berasal dari pengeluaran pelaku usaha yang berada di Kabola, sedangkan proporsi pendapatan pelaku usaha saat weekday dibandingkan dengan weekend adalah $29 \%: 71 \%$. Sebagian besar pengeluaran unit usaha digunakan untuk biaya rumah tangga dan biaya operasional unit usaha, seperti untuk pembelian bahan baku, pemeliharaan alat, upah tenaga kerja, dan lainnya. Pada umumnya pelaku usaha tidak mengeluarkan biaya sewa (tempat usaha adalah milik pribadi). Untuk upah tenaga kerja memiliki proporsi paling besar yaitu sebanyak $36 \%$, biaya pemeliharaan alat sebesar $25 \%$, biaya operasional sebesar $15 \%$, biaya rumah tangga sebesar $9 \%$, biaya pembelian bahan baku sebesar $4 \%$, dan retribusi/pajak $1 \%$. Jumlah tenaga kerja yang terkait dengan kegiatan wisata di Kabola masih minim yaitu 29 orang. Dampak ekonomi tidak langsung dapat dihitung melalui pendapatan yang diperoleh tenaga kerja lokal. Rata-rata pendapatan tenaga kerja perbulan sebesar Rp1.142.308,- per bulan. Total pendapatan yang paling tinggi adalah karyawan café sebesar Rp1.500.000,- per bulan baik sebagai security, kasir, maupun pelayan. Total pendapatan paling kecil adalah pedagang keliling dan pedagang kaki lima makanan sebesar Rp200.000-400.000 per bulan. Dampak ekonomi tidak langsung yang diperoleh dari kegiatan wisatawan di Kabola sebesar Rp201.600.019 per tahun (Tabel 2).

Tabel 1. Dampak Ekonomi Langsung Kegiatan Wisata di Kabola, Kabupaten Alor Tahun 2019. Tabel 1. Direct Economic Impacts of Tourism Activities in Kabola, Alor Regency in 2019.

\begin{tabular}{lccc}
\hline \multicolumn{1}{c}{ Jenis Usaha/ Type of Business } & $\begin{array}{c}\text { Jumlah Populasi/ } \\
\text { Total Population }\end{array}$ & $\begin{array}{c}\text { Rata-rata Pendapatan } \\
\text { (Rp/tahun/unit)/Average } \\
\text { Income (IDR/tahun/unit) } \\
\text { (b) }\end{array}$ & $\begin{array}{c}\text { Dampak Ekonomi } \\
\text { Langsung (Rp)/ Direct } \\
\text { Economic Impact (IDR) } \\
\text { (e=a*b) }\end{array}$ \\
\hline Warung kelontong/Grocery store & 2 & $36,000,000$ & $72,000,000$ \\
PKL makanan/Street food vendors & 8 & $18,000,000$ & $144,000,000$ \\
Sewa Alat Selam/Scuba Dive & 3 & $12,000,000$ & $36,000,000$ \\
equipment rental & 1 & $18,000,000$ & $18,000,000$ \\
Jasa usaha wisata lokal/Local travel & 1 & $18,000,000$ & $90,000,000$ \\
business services & 5 & $24,000,000$ & $180,000,000$ \\
Pedagang keliling/Peddler & 5 & & $\mathbf{5 4 0 , 0 0 0 , 0 0 0}$ \\
Unit usaha campuran/Mix business unit & & &
\end{tabular}


Tabel 2. Dampak Ekonomi Tidak Langsung Kegiatan Wisata di Kabola, Kabupaten Alor Tahun 2019. Table 2. Indirect Economic Impacts of Tourism Activities in Kabola, Alor Regency in 2019.

\begin{tabular}{|c|c|c|c|c|}
\hline Jenis Usaha/ Type of Business & PPTK & PDTK & PNUU & DETL \\
\hline Warung kelontong/Grocery store & 2 & $12,000,000$ & $2,400,000$ & $19,200,000$ \\
\hline PKL makanan/Street food vendors & 5 & $6,000,000$ & $1,200,000$ & $7,200,005$ \\
\hline Sewa alat /Equipment rental & 3 & $7,200,000$ & $2,400,000$ & $9,600,003$ \\
\hline Jasa usaha wisata/Travel business service & 1 & $8,400,000$ & $2,400,000$ & $10,800,001$ \\
\hline Pedagang keliling/Peddler & 5 & $6,000,000$ & $2,400,000$ & $8,400,005$ \\
\hline Unit usaha campuran/Mix business unit & 5 & $6,000,000$ & $2,400,000$ & $8,400,005$ \\
\hline Total (A) & & & & $63,600,019$ \\
\hline \multicolumn{5}{|l|}{ Tenaga kerja/ Labor } \\
\hline Warung makan/Restaurant & 2 & $24,000,000$ & $9,000,000$ & $30,000,000$ \\
\hline Petugas kebersihan/Cleaning service & 2 & $24,000,000$ & $6,000,000$ & $36,000,000$ \\
\hline Jasa usaha wisata/Travel business service & 3 & $24,000,000$ & $6,000,000$ & $54,000,000$ \\
\hline Penjaga toilet/Toilet guards & 1 & $24,000,000$ & $6,000,000$ & $18,000,000$ \\
\hline Total (B) & & & & $138,000,000$ \\
\hline Keseluruhan $(A+B) /$ Total $(A+B)$ & & & & $201,600,019$ \\
\hline
\end{tabular}

Keterangan/Remarks:

PPTK : Populasi tenaga kerja (orang)/ Labor population (people)

PDTK : Pendapatan tenaga kerja (Rp/tahun)/ Labor income (IDR/year)

PNUU : Pengeluaran unit usaha di kawasan wisata (Rp/tahun)/ Expenditures of business units in tourist areas (IDR/ year)

DETL : Dampak ekonomi tidak langsung / Indirect economic impact

Dampak ekonomi lanjutan (induced impact) merupakan dampak ekonomi yang diperoleh berdasarkan pengeluaran yang dikeluarkan oleh tenaga kerja lokal yang berada di kawasan wisata Kabola. Menurut Putra, Wijayanti, \& Prasetyo (2019) dampak lanjutan yaitu perubahan dalam kegiatan ekonomi yang dihasilkan dari pengeluaran rumah tangga dari pendapatan yang diperoleh baik secara langsung maupun tidak langsung. Jenis pengeluaran yang dikeluarkan tenaga kerja lokal antara lain digunakan untuk biaya konsumsi, biaya sekolah anak, biaya listrik, biaya kebutuhan sehari-hari, biaya transportasi, biaya barang tahan lama, biaya beli pakaian, biaya kesehatan, dan biaya lainnya. Sebagian besar pengeluaran tenaga kerja lokal di di kawasan wisata Kabola digunakan untuk biaya kebutuhan sehari-hari (pengeluaran pangan) sebesar $79 \%$, dan non pangan sebesar $21 \%$. Dampak lanjutan melihat pengeluaran tenaga kerja yang dibelanjakan di unit usaha yang berada di Kabola. Dampak lanjutan dari pengeluaran tenaga kerja ini akan diterima oleh unit usaha dan sebagian pendapatan yang diterima unit usaha digunakan untuk membeli bahan baku. Dampak lanjutan berupa pengeluaran tenaga kerja lokal yang kembali berputar di tingkat ekonomi lokal. Sebagian besar pendapatan yang mereka dapatkan, mereka belanjakan di unit-unit usaha, seperti, kios warung dan warung makan guna memenuhi kebutuhan sehari-hari dan konsumsi. Secara tidak langsung unit usaha yang berada di Kabola selain menerima pendapatan dari pengeluaran wisatawan yang datang, unit usaha inipun menerima pendapatan dari pengeluaran tenaga kerja.

Tabel 3. Dampak Ekonomi Lanjutan Kegiatan Wisata di Kabola, Kabupaten Alor Tahun 2019. Table 3. Induced Economic Impacts of Tourism Activities in Kabola, Alor Regency in 2019.

\begin{tabular}{lcccc}
\hline \multicolumn{1}{c}{ Tenaga kerja/ labor } & JTKL & TPTK & PPKW & DMEL \\
\hline Warung makan/Restaurant & 2 & $9,000,000$ & $37.50 \%$ & $6,750,000$ \\
Petugas kebersihan/Cleaning service & 5 & $6,000,000$ & $25.00 \%$ & $7,500,000$ \\
Jasa usaha wisata/Travel business services & 3 & $6,000,000$ & $25.00 \%$ & $4,500,000$ \\
Penjaga toilet/Toilet guards & 1 & $6,000,000$ & $25.00 \%$ & $1,500,000$ \\
\hline \multicolumn{1}{c}{ Total Per Tahun/ Total Per Year } & & & & $\mathbf{2 0 , 2 5 0 , 0 0 0}$ \\
\hline
\end{tabular}

Keterangan/Remarks:

JTKL : Jumlah tenaga kerja lokal (orang)/Number of local labor (people)

TPTK : Total pengeluaran tenaga kerja (Rp/tahun)/Total labor expenditure (IDR/year)

PPKW : Proporsi Pengeluaran di Kawasan wisata (\%)/Proportion of expenditures in tourist areas (\%)

DMEL : Dampak ekonomi lanjutan (Rp) (JTKL*TPTK*PPKW)/ Induced economic Impacts (IDR) 
Secara umum, seluruh keperluan atau kebutuhan tenaga kerja didapat dari dalam lokasi Kabola dan Kalabahi. Oleh karena itu, jika dilihat dari sumber daya alamnya Kabola memiliki sumber daya alam yang masih mencukupi karena hampir seluruh kebutuhan dan keperluannya ada di dalam daerah. Dampak ekonomi lanjutan kegiatan wisata bahari di Kabola sebesar Rp20.250.000 per tahun dapat dilihat pada Tabel 3.

\section{Nilai Efek Pengganda (Multiplier Effect)}

Dampak ekonomi dari pengeluaran wisatawan yang terjadi di Kabola dapat diukur dengan menggunakan nilai efek pengganda atau multiplier effect dari aliran uang yang terjadi. Efek pengganda dapat dilihat dari jumlah pengeluaran wisatawan selama melakukan wisata di Kabola. Berdasarkan hasil analisis didapatkan nilai Keynesian Income Multiplier sebesar 1,72 yang artinya setiap terjadi peningkatan pengeluaran wisatawan sebesar 1 rupiah, maka akan berdampak terhadap peningkatan pendapatan tenaga kerja dan para pemilik unit usaha di lokasi wisata diduga sebesar 1,72 rupiah dapat dilihat pada Tabel 4 .

Nilai Ratio Income Multiplier Tipe I yang telah didapatkan sebesar 1,04 yang artinya apabila terjadi peningkatan sebesar 1 rupiah terhadap pemilik unit usaha, maka akan berdampak terhadap peningkatan pendapatan tenaga kerja lokal diduga sebesar 1,04 rupiah (berupa pendapatan bersih unit usaha dan upah tenaga kerja), selanjutnya nilai yang diperoleh dari Ratio Income Multiplier Tipe II sebesar 1,08 yang artinya apabila terjadi peningkatan sebesar 1 rupiah terhadap pendapatan pemilik unit usaha, maka akan berdampak terhadap peningkatan pada dampak langsung, tidak langsung, dan lanjutan (berupa pendapatan pemilik unit usaha, tenaga kerja,serta pengeluaran untuk konsumsi di tingkat lokal) yang diduga sebesar 1,08 rupiah. Arti dari nilai RIM tersebut juga diungkapkan oleh Saiful, Hesti \& Muhammad, 2019 dalam penelitiannya tentang dampak ekonomi dari wisata bahari Pantai Jangka, Bireuen, Aceh.

Dampak ekonomi ini sedikit lebih rendah dibanding kegiatan ekowisata lain seperti Ekowisata Hiu Paus di Gorontalo (Wolok, 2016) dan wisata bahari di Kepulauan Seribu (Aryunda, 2011), serta wisata bahari di Pulau Tidung (Dritasto \& Anggaeni, 2013). Dampak ekonomi seperti wisata bahari di daerah lain seperti di Aceh dalam penelitian (Saiful et al., 2019) juga menunjukkan nilai RIM dan KIM >1 yang artinya kegiatan wisata bahari tersebut memberikan dampak ekonomi bagi masyarakat setempat. Ekowisata Hiu paus di Gorontalo mencapai nilai Rasio Income Multiplier effect type II sebesar 1,97. Hal ini dikarenakan ekowisata Hiu Paus sudah lama dan lebih berkembang dibandingkan ekowisata Dugong di Alor.

Tabel 4. Nilai Pengganda dari Arus Perputaran Uang di Kabola, Kabupaten Alor Tahun 2019. Table 4. Multiplier Effect of the Money Circulation in Alor Regency in 2019.

\begin{tabular}{|c|c|c|c|}
\hline No. & Kriteria/Criteria Multiplier & $\begin{array}{l}\text { Nilai (Rp)/ } \\
\text { Value (IDR) }\end{array}$ & Keterangan/Remaks \\
\hline 1. & $\begin{array}{l}\text { Pengeluaran wisata di lokasi wisata per tahun }(\mathrm{E}) / \\
\text { Tourism expenses at tourist sites per year }\end{array}$ & $3,600,000,000$ & \\
\hline 2. & $\begin{array}{l}\text { Dampak langsung per tahun (D)/ direct impact per } \\
\text { year }\end{array}$ & $5,760,000,000$ & \\
\hline 3. & $\begin{array}{l}\text { Dampak tidak langsung per tahun }(\mathrm{N}) / \text { indirect } \\
\text { impact per year }\end{array}$ & $201,600,019$ & \\
\hline 4. & $\begin{array}{l}\text { Dampak lanjutan per tahun }(\mathrm{U}) / \text { induced impact per } \\
\text { year }\end{array}$ & $243,000,000$ & \\
\hline & Keynensian Income Multiplier $((D+N+U) / E)$ & 1.72 & $\begin{array}{l}\text { Dampak ekonomi yang terjadi } \\
\text { dikatakan telah memberikan } \\
\text { dampak ekonomi terhadap } \\
\text { kegiatan wisata karena nilai } \\
\text { Keynesian income multiplier, } \\
\text { Ratio Income Multiplier Tipe I } \\
\text { dan Ratio Income Multiplier Tipe } \\
\text { II adalah lebih besar atau sama } \\
\text { dengan satu }(\geq 1)\end{array}$ \\
\hline 6. & Ratio Income Multiplier Tipe I (D+N/D) & 1.04 & \\
\hline 7 & Ratio Income Multiplier Tipe II $(D+N+U / D)$ & 1.08 & \\
\hline
\end{tabular}




\section{KESIMPULAN DAN REKOMENDASI KEBIJAKAN}

\section{Kesimpulan}

Hasil analisis menunjukkan bahwa dampak ekonomi langsung yang diperoleh dari kegiatan wisatawan di Kabola sebesar Rp480.000.000 per tahun dan dampak ekonomi tidak langsung yang diperoleh dari kegiatan wisatawan di Kabola sebesar Rp201.600.019 per tahun, serta dampak ekonomi lanjutan kegiatan wisata bahari di Kabola sebesar Rp20.250.000 per tahun. Berdasarkan hasil analisis didapatkan nilai Keynesian Income Multiplier sebesar 1,72 yang artinya setiap terjadi peningkatan pengeluaran wisatawan sebesar 1 rupiah, maka akan berdampak terhadap peningkatan pendapatan tenaga kerja dan para pemilik unit usaha di lokasi wisata diduga sebesar 1,72 rupiah dan nilai Ratio Income Multiplier Tipe I sebesar 1,04 serta nilai Ratio Income Multiplier Tipe II sebesar 1,08, sehingga dapat disimpulkan bahwa kegiatan wisata yang ada di Kabupaten Alor memiliki dampak ekonomi bagi masyarakat Kabupaten Alor.

Multiplier Income ekowisata di Alor cukup tinggi walaupun secara magnitude jumlah wisata tidak sebanyak wisatawan di tempat lain seperti Bali dan Lombok. Saat ini, pemasaran ekowisata di Alor sudah dibantu oleh jaringan agen-agen tour dan keberadaan Lembaga Swadaya Masyarat (LSM) yang membantu konservasi alam di Alor seperti WWF Indonesia.

\section{Rekomendasi Kebijakan}

Semakin lama wisatawan menghabiskan waktu untuk berwisata, maka akan semakin banyak transaksi ekonomi yang dilakukan di daerah tersebut dan perputaran uang akan menjadi lebih lama, sehingga dampak ekonomi yang didapat dari nilai RIM dan KIM juga akan meningkat. Oleh sebab itu, perlu adanya peningkatan fasilitas wisata seperti tour package yang tidak hanya menyediakan paket wisata saja namun juga menawarkan paket edukasi untuk anak-anak yang sedang libur sekolah. Hal ini dapat berbentuk camping, atau sekolah alam dalam jangka waktu yang lebih lama.

Sertifikasi dan training terhadap para pelaku usaha kegiatan wisata seperti tour guide, koki restoran, dan lain-lain penting untuk dilakukan untuk meningkatkan nilai tambah servis yang dihasilkan dan akhirnya peningkatan nilai dampak ekonomi dan multiplier effect dari kegiatan wisata bahari di Kabupaten Alor.
Diversifikasi tempat ekowisata di Alor juga perlu dilakukan untuk meningkatkan length of stay dari para wisatawan dan peningkatan dampak ekonomi ke masyarakat lokal. Hal ini dapat dilakukan melalui pemasaran dalam bentuk tour package maupun pengenalan tempat-tempat baru sewaktu acara ALOR EXPO yang digelar tiap tahun oleh Pemerintah Kabupaten Alor.

\section{UCAPAN TERIMA KASIH}

Penulis mengucapakan terima kasih kepada anggota tim penelitian ekonomi kreatif berbasis budaya bahari di BBRSEKP dan Tommi Febian atas bantuan dalam pengumpulan data primer efek pengganda. Kami ucapkan terima kasih kepada para enumerator lapangan yang membantu tim peneliti BBRSEKP dalam pengumpulan data. Serta, kami sampaikan terima kasih kepada stakeholders yang terlibat sehingga kegiatan Focus Group Discussion dapat terlaksana dengan baik.

\section{PERNYATAAN KONTRIBUSI PENULIS}

Umi Muawanah sebagai kontributor utama dalam karya tulis ilmiah ini mendesain penelitian, melakukan pengambilan data di lapangan, dan analisis data, serta menulis manuskrip. Riesti Triyanti dan Permana Soejarwo Ari sebagai kontributor anggota bersama-sama mendesin penelitian, mengumpulkan data di lapangan, dan meninjau naskah. Tidak lupa, ucapan terima kasih kepada Tommi Febrian sebagai enumerator survey dampak ekonomi di Alor.

\section{DAFTAR PUSTAKA}

Aryunda, H. (2011). Dampak ekonomi pengembangan kawasan ekowisata Kepulauan Seribu. Jurnal Perencanaan Wilayah dan Kota. 22(1):1-16. DOI: http://dx.doi.org/10.5614\%2Fjpwk.2011.22.1.1

Badan Pusat Statistik NTT. (2018). Capaian indikator kinerja sasaran Dinas Pariwisata Nusa Tenggara Timur tahun 2018.

Beckenstein, A. \& Appleyard, M \& Christmann, P. (2008). The Income Multiplier.

Dritasto, A. \& Anggraeni, A.A. (2013). Analisis Dampak Ekonomi Wisata Bahari Terhadap Pendapatan Masyarakat di Pulau Tidung. Jurnal Online ITN. 10(20). Retrieved: https://media.neliti.com/media/ publications/220893-none.pdf

Dinas Pariwisata dan Ekonomi Kreatif Provinsi Nusa Tenggara Timur (2018). Fenomena Air Laut Dingin. 
Efrilingga, A. (2014). Dampak Pembangunan Pariwisata terhadap Kondisi Sosial Ekonomi Kehidupan Masyarakat (Studi pada Wisata Bahari Lamongan Kecamatan Paciran). Doctoral dissertation. Universitas Brawijaya.

Frechtling, D. C. \& Horvath, E. (1999). Estimating the multiplier effects of tourism expenditures on a local economy through a regional inputoutput model. Journal of travel research,37(4), 324-332. DOI:doi.org/ $10.1177 / 004728759903700402$.

Hughes, H. L. (1994). Tourism multiplier studies: a more judicious approach. Tourism Management, 15(6), 403-406.

Jubaedah, I., \& Anas, P. (2019). Dampak Pariwisata Bahari Terhadap Ekosistem Terumbu Karang di Perairan Nusa Penida, Bali. Jurnal Penyuluhan Perikanan dan Kelautan, 13(1), 59-75. DOI: 10.33378/jppik.v13i1.124

Khan, H., Phang, S. Y. \& Toh, R. S. (1995). The multiplier effect: Singapore's hospitality industry. Cornell Hotel and Restaurant Administration Quarterly, 36(1), 64-69.

Kementerian Perencanaan Pembangunan Nasional Republik Indonesia/ PPN Bappenas. (2003). Gambaran umum Kabupaten Alor. Jakarta.

Kumar, J., \& Hussain, K. (2014). Evaluating tourism's economic effects: Comparison of different approaches. Procedia-Social and Behavioral Sciences, 144, 360-365. DOI: https://doi. org/10.1016/j.sbspro.2014.07.305

Kurniasari, N., Muawanah, U., Zulham, A., Koeshendrajana, S., Triyanti, R., Soejarwo, P. A,. \& Yuliaty, C. (2018). Kajian Dampak Sektor Priwisata terhadap Perekonomian Indonesia. Lembaga Penyelidikan Ekonomi dan Masyarakat Fakultas Ekonomi dan Bisnis Universitas Indonesia.

Mathieson, A. \& Wall, G. (1982). Tourism: Economic, Physical and Social Impacts. Oxford: Pitman Publishing.

[META] Marine Ecotourism for Atlantic Area. (2000). Marine Ecotourism in The Eu Atlantic Area: Issues and Experiences. Britol (GB): University of The West Of England.

[META] Marine Ecotourism for Atlantic Area. (2001). Planning for Marine Ecotourism in The Eu Atlantic Area. Britol (GB): University of The West Of England.

Mulyadi I. \& Santoso, M. S. (2013). Efek Pengganda Pengeluaran Wisatawan Nusantara Studi Kasus: Destinasi Ketep Pass Kabupaten Magelang. [Tesis]. UGM University.
Rahma, F. N. \& Handayani, H. R. (2013). Pengaruh jumlah kunjungan wisatawan, jumlah obyek wisata dan pendapatan perkapita terhadap penerimaan sektor pariwisata di Kabupaten Kudus. Diponegoro Journal of Economics, 109-117.

Rahmatika, A., Kusumastanto, T., \& Sadelie, A. (2017). Manajemen Pengembangan Kebijakan Wisata Bahari Di Kawasan Ekonomi Khusus Mandalika Lombok Tengah: Studi Kasus Pantai Kuta. Jurnal Manajemen, 21(3), 381-397. DOI: https://doi.org/10.24912/jm.v21i3.258

Rema, N. \& Prihatmoko, H. (2016). Potensi Arkeologi di Pulau Alor. KALPATARU, 25(2), 103.

Patji, A. (2009). Makassar Nama Kolektif: Masyarakat Migran Sulawesi Selatan di Alor Kecil, Kabupaten Alor, Nusa Tenggara Timur. Jurnal Masyarakat dan Budaya, 11(2), 151-175.

Putra, A. P., Wijayanti, T., \& Prasetyo, J. S. (2019). Analisis Dampak Berganda (Multiplier Effect) Objek Wisata Pantai Watu Dodol Banyuwangi. Journal of Tourism and Creativity, 1(2).

Pemerintah Provinsi Nusa Tenggara Timur. (2018). Capaian indikator kinerja sasaran Dinas Pariwisata Nusa Tenggara Timur tahun 2018.

Priyanto, S. E., \& Par, M. (2016). Dampak Perkembangan Pariwisata Minat Khusus Snorkeling Terhadap Lingkungan: Kasus Destinasi Wisata Karimunjawa. Jurnal Kepariwisataan, 10(3),13-28.

Putra, A. P., Wijayanti, T. \& Prasetyo, J.S. (2017) Analisis Dampak Berganda (Multiplier Effect) pbjek wisata pantai Watu Dodol Banyuwangi. Journal of tourism and creativity. 1(2):141-154.

Saiful, A., Hesti, M. \& Muhammad, N. (2019). The impact of the economic activities of marine tourism in Jangka Beach, jangka mesjid village of Jangka Bireuen subdistrict, Indonesia. Russian Journal of Agricultural and Socio-Economic Sciences, 91(7).

Stynes, D. J., Propst, D. B., Chang, W. \& Sun, Y. (2000). Estimating national park visitor spending and economic impacts; The MGM2 Model. Report to the National Park Service. East Lansing, MI: Department of Park, Recreation and Tourism Resources, Michigan State University.

Subadra, I. N., \& Nadra, N. M. (2012). Dampak ekonomi, sosial-budaya, dan lingkungan pengembangan desa wisata di Jatiluwih-Tabanan. Jurnal Manajemen dan Pariwisata II, 5(1).

Vanhove, N. (2005). The economics of tourism destinations, Elseveir Limited ButterworthHeinemann, UK. 
Wahyudin, Y. (2003). Sistem sosial ekonomi dan budaya masyarakat pesisir. Disampaikan pada Pelatihan Pengelolaan Kawasan Konservasi Perairan. PKSPL-IPB. Bogor.

Wahyudin, Y. (2003). Sistem sosial ekonomi dan budaya masyarakat pesisir. Makalah disampaikan pada pelatihan Pengelolaan Kawasan Konservasi Perairan.

Wolok, E. (2016). Analisis Dampak Ekonomi Wisata Hiu Paus Terhadap Pendapatan Masyarakat Batubarani Gorontalo. Jurnal Ekonomi Bisnis dan Kewirausahaan (JEBIK), 5(2), 136-143.

Yasa, I. N. M. (2015). Pengaruh jumlah kunjungan wisatawan, lama tinggal wisatawan dan tingkat hunian hotel terhadap Pendapatan Asli Daerah dan kesejahteraan masyarakat pada Kabupaten/Kota di Provinsi Bali. E-Jurnal Ekonomi Pembangunan Universitas Udayana, 6(7), 165233. 